The University of San Francisco

USF Scholarship: a digital repository@ Gleeson Library |

Geschke Center

Economics

College of Arts and Sciences

2002

\title{
Microfinance among the Maya: Tracking the Progress of Borrowers
}

Bruce Wydick

University of San Francisco, wydick@lucas.usfca.edu

Follow this and additional works at: http://repository.usfca.edu/econ

Part of the Economics Commons

\section{Recommended Citation}

Wydick, Bruce, "Microfinance among the Maya: Tracking the Progress of Borrowers" (2002). Economics. Paper 17. http://repository.usfca.edu/econ/17

This Article is brought to you for free and open access by the College of Arts and Sciences at USF Scholarship: a digital repository @ Gleeson Library | Geschke Center. It has been accepted for inclusion in Economics by an authorized administrator of USF Scholarship: a digital repository @ Gleeson Library | Geschke Center. For more information, please contact repository@usfca.edu. 


\title{
Tracking the Progress of 239 Microcredit Program Participants in Guatemala: 1994-1999
}

\author{
Bruce Wydick \\ Assistant Professor \\ Department of Economics \\ University of San Francisco
}

\begin{abstract}
April 2001
Abstract: Programs that make credit available to small-scale entrepreneurs in developing countries have become an increasingly widespread tool for stimulating economic growth among the poor. This study tracks the progress of 239 participants over five years in a microcredit program in western Guatemala, relying on a survey of borrowers taken in 1994 and a re-survey of these borrowers in 1999. Important results from the study the show that while rapid and significant increases in hired labor were realized by enterprises in the sample shortly after initial access to credit, this growth in employment generation quickly encountered diminishing returns, and in some cases became negative. Other results from the study highlight gender differences in response to credit access, with female entrepreneurs displaying greater enterprise stability, and greater propensity to use profits for household consumption rather than enterprise re-investment.
\end{abstract}

*Wydick: University of San Francisco, 2130 Fulton Street, San Francisco, CA $94117-$ 1080, e-mail: wydick@usfca.edu. Financial support from the Pew Charitable Trust Evangelical Scholars Program is gratefully acknowledged. 


\section{INTRODUCTION}

A fundamental shift in development policy has occurred in recent years toward promoting entrepreneurship among the poor in developing countries. This change is reflected in the vast proliferation of microcredit programs and participants in these programs across the developing world, such that now there are over 10,000 microcredit institutions worldwide. Since 1997, approximately 1600 of the largest of these institutions have been working in a coordinated effort to reach 100 million of the world's poor households by 2005 (Microcredit Summit Campaign Report, 2000). Reports from these institutions now reveal 23.5 million households reached by microcredit, including 18.4 million in Asia, 3.8 million in Africa, and 1.1 million in Latin America.

The now widespread use of microcredit as a development tool has produced a critical need for research analyzing the long-term changes among those who borrow from microcredit institutions. This research examines the changes that took place from 1994 to 1999 among 239 participants in a microcredit program in western Guatemala, focusing on both changes in borrowers' enterprises as well as changes in household welfare.

Important studies on the impact of microcredit programs have been carried out by Hulme and Mosley (1996), Khandker (1998), Morduch (1998), and Coleman (1999). The study of Hulme and Mosley (1996) is significant because in focuses on eight microcredit programs on three continents. Hulme and Mosley generally find strong and significant impacts on borrowers with access to microcredit programs relative to control groups. Interestingly, borrower impact is found to be stronger for institutions with greater levels of self-sufficiency. Using a carefully designed survey technique that controls for selection bias, Coleman (1999), however, finds little significant impact from a program operating in Northeast Thailand over a one-year study period. These results, 
he notes, may be due to the relatively small sizes of the loans in proportion to the fairly high level of assets held by program participants in the Thai program.

Khandker's (1998) study from a 1991-92 survey in Bangladesh is distinctive because of the way it econometrically controls for endogeneity in program placement. Key results from Khandker's study highlight the significant impact of credit access provided by the three largest microcredit programs in Bangladesh: the Grameen Bank, Bangladesh Rural Advancement Committee (BRAC), and Rural Development Project 12 (RD-12). Among other interesting findings, Khandker's study shows that about 5 percent of households participating in the three programs are lifted above the official poverty line each year. Khandker also highlights gender differences in program impact. He finds that the impact on household consumption of the credit programs to be approximately twice as large for female borrowers as for male borrowers. Morduch's (1998) subsequent study uses the same data set with an alternative econometric technique to control for endogenous program placement. While his study is unable to corroborate some of the results of Khandker (Pitt and Khandker, 1998) related to the impact of credit access on consumption and schooling, he does find credit access to result in a significant level of consumption smoothing across seasons.

The research presented here is distinguished from these studies in that it is a product of two first-hand surveys of the same, somewhat smaller, group of borrowers five years apart. In this way, its purpose is not to present econometric tests of program impact, but to understand longer-term issues and patterns of development among borrowers in microcredit programs. Moreover, this research seeks to contextualize changes in the status and welfare of the Guatemalan program participants in the regional and global economy during the late 1990s. From this, the study hopes to differentiate and 
understand obstacles faced by microcredit program participants that are specific to the context of the Guatemalan borrowers, as well as those that are faced by low-income entrepreneurs in developing countries more generally.

The initial data for this research was collected in 1994 when 239 entrepreneurs who were participants in a microcredit program were surveyed in Quetzaltenango, Guatemala and its surrounding rural area. Data was obtained on the number of employees in the entrepreneurs' enterprises, business income, and initial impacts of the credit program on these variables and other variables relating to household welfare. Five years later in 1999, the same individuals were located and given a similar interview, which attempted to ascertain real changes in economic and welfare variables over the period 1994-1999.

An important finding from this research is that almost immediately upon receiving access to credit, small enterprises in the study (especially those involved in manufacturing) typically realized a burst of growth in capital accumulation, in the number of hired employees in the enterprise, and business revenue. However, the study shows that growth tended to plateau quickly after the addition of two or three employees. After this point, incremental increases in hired labor were found to be very small, and frequently negative. Income from microenterprises, however, continued to increase, though not as rapidly as in the months directly following initial credit access.

Similar to studies by Khandker and others, the 1999 follow-up study likewise sought to understand the long-term gender differences in impacts of credit programs. Indeed this research corroborates the existence of differences in behavior between male and female entrepreneurs ex-post to credit access. Enterprises operated by female entrepreneurs appeared in many ways to be more stable than those operated by men. For 
example, drop-out rates from the credit program were much lower among female interpreters, as were rates of transition back into the non-entrepreneurial labor market and instances of foreign emigration. Moreover, the study found significant differences in the use of enterprise profits between male and female entrepreneurs. Male entrepreneurs in the survey showed a greater disposition to redirect profits into enterprise investment and hired labor, while female entrepreneurs placed a higher priority on using profits to increase household consumption.

The remainder of the paper is organized as follows: Section II presents a brief discussion of the history of the survey area and the survey methodology. Section III shows changes in borrower status by demographic characteristics over the five-year period of the study, the number of borrowers remaining in the credit program, and those leaving entrepreneurial activity for both domestic and international labor markets. In Section IV the paper examines changes in employment and enterprise revenue within the enterprises. Gender differences in response to credit access are discussed in Section V. Section VI concludes with development policy implications for microfinance institutions.

\section{THE WESTERN GUATEMALAN REGION AND 1994, 1999 CREDIT SURVEYS}

Western Guatemala is one of the most densely populated rural areas in

Central America. The continual process over generations of dividing land between heirs has substantially diminished the amount of land tenured by the average household. Today a Quiché Indian family living in the region regularly subsists on less than an acre of land. On this land routinely sits a small adobe house with a dirt floor, space for a few farm animals, and the plot of land on which the household cultivates its milpa, or corn crop. The intense population pressure has left its scar on a breathtaking mountainous 
landscape; it has pushed plots of milpa up the side of steep and rocky mountains, onto land better suited for wild foliage than for cultivation.

Some households have coped with the regional scarcity of land through migration to the capital city. These rural migrants often find work in the maquiladoras, factories owned by foreign firms attracted by Guatemala's low wages. Other households cope with the scarcity of land by establishing nonagricultural household enterprises. These household enterprises are often established through the occasional surplus realized through agricultural activities: the selling of a farm animal, an above average crop yield, or wages earned from working on a neighbor's plot.

Household enterprises, however, encounter enormous obstacles to growth in western Guatemala, as they do in virtually every region of the developing world. Paramount among these obstacles is the scarcity of capital in poor areas. When enterprises achieve a sufficient level of capitalization, they are able to generate a surplus above subsistence needs of the household. This surplus can be funneled into business investment, which in turn generates further growth. However, an enormous number of households in areas such as western Guatemala are caught in a poverty trap in which insufficient capitalization constrains the enterprise from generating enough income to allow for additional investment.

One might think that this dynamic would dissipate with the existence of credit markets since access to credit allows for enterprise investment when surpluses are inadequate to increase enterprise capitalization. However, problems stemming from information asymmetries between borrowers and a lender in credit transactions create a need for costly screening procedures. Because the costs of these procedures are only 
justified for large-scale borrowers, the entrepreneurial poor are routinely denied access to formal credit markets.

Credit market failures in developing countries thus create an economic environment in which the household enterprises of the poor can remain perpetually undercapitalized, even though the return on capital investment in these enterprises may be quite high. Such a situation was pervasive in western Guatemala in the mid-1980's when FUNDAP ${ }^{1}$, a non-governmental institution, founded a credit delivery program targeted at household enterprises in the region. Through an innovative credit delivery system based on models developed by the Grameen Bank and ACCION International, FUNDAP's mission has been to provide access to credit to the entrepreneurial poor in western Guatemala. The credit institution currently has thirteen offices in the region, a portfolio of 5,709 borrowers, and an active portfolio balance of US\$2,743,643.

The 1994 and 1999 surveys were carried out in conjunction with FUNDAP in two principal regions in western Guatemala, the area in and around the city of Quetzaltenango (pop. 96,000) and the rural areas surrounding the town of Totonicapán (pop. 9000), 32 miles to the northeast of Quetzaltenango. Most of the residents of the region are Quiché, speaking first their native language but also Spanish. The Quiché have been the major people group in the region since the 14th century, when they began a significant expansion into the area, which had been principally dominated by the Mam. Both groups are descendants of the Maya, who established the center of their civilization hundreds of kilometers to the northeast that reached its peak centuries earlier around 600-900 A.D. The individuals who were surveyed were representative of the general population of the region: principally Quiché (and a few Mam) borrowers in the rural villages, with a small but significant group of Ladino borrowers in the urban areas. 
The sample of borrowers in the initial 1994 survey was a mix of $23 \%$ comerciantes (retailers,) and 77\% productores (light manufacturers), which roughly reflected the proportion of the two types of activities in FUNDAP's lending portfolio. Productores were engaged in a wide range of activities, often fabricating corte (traditional Guatemalan cloth) on wooden looms in their own homes. Other productores produced shoes, candles, clay pots, bread, or other goods for which economies of scale are non-essential for market production. Comerciantes located in rural villages often owned and managed small corner shops selling a variety of household staples. Those in urban areas tended to be more specialized, buying fruits, vegetables, meat, or clothes on a wholesale basis and then selling them from rented spaces in the large local markets. Approximately $25 \%$ of the borrowers in FUNDAP's portfolio were women, as are a similar proportion currently.

In each area, the survey was carried out with the help of the FUNDAP credit officer assigned to the specific region targeted for surveying. In the urban area of Quetzaltenango itself, 43 borrowers were surveyed, while in the mountainous rural areas surrounding Quetzaltenango, 106 borrowers were surveyed. The latter borrowers were located in and around the small town of Cantel, about 10 kilometers to the east of Quetzaltenango, in Palomora, a rural village situated at an elevation of 3000 meters in the high mountains about 15 kilometers north of Quetzaltenango, and in seven small rural villages within about 20 kilometers of the city: Tzamboj, Xeraxaj, Paxtaca, Vasquez, San Ramon, Pachaj, and Nimasac.

In the Totonicapán region, 90 borrowers were surveyed, and except for four urban borrowers located within the town of Totonicapán itself, participants in the credit 
programs were located in the surrounding rural areas in the villages of Paqui, Juchanup, Nimapá, Patzaracmac, Chusacmalja, Xolzacmalja, Poxlajuj, Xelscmalja, and Chuisuc. Borrowers in all areas appear to be heavily credit constrained at the time of the 1994 survey without the access to credit provided by FUNDAP. By 1999, however, a number of other microcredit programs had begun to more firmly establish operations in the area $^{2}$, and in some areas FUNDAP had actually begun to lower interest rates for larger borrowers to compete with other credit institutions.

To more accurately assess the impact of sustained access to a microcredit program, the 1999 survey included a survey of a control group of 140 borrowers in the credit program who had received their first loan within the last year. The control group consisted of new borrowers to the credit program to minimize well-known problems of self-selection bias in assessing the impact of programs in which individuals freely choose to participate. The problem of self-selection bias stems from the difficulty in separating unobservable characteristics (such as entrepreneurial drive) between treatment and control groups from the actual effects of the program itself. In this way it was possible to compare changes in key variables over a five-year period between entrepreneurs who had been in the program and 1994 and entrepreneurs who were not in the credit program during this period (but who gained access to it eventually as the credit program reached their area by 1999), and thus more accurately reveal the actual effects of the credit program. Data was obtained from the control group for full-time hired labor within the enterprise, business revenue, and other variables at the time of the 1999 survey itself, one month before entry into the credit program, and five years before joining the credit program. Because of the nature of the survey, it was necessary to carefully elicit recall data for the historical figures, but it was felt that any losses in accuracy from recalling 
historical data was more than compensated for by the elimination of self-selection bias in the control group.

\section{TRACKING PROGRAM PARTICIPANTS 1994-1999}

A primary goal of the 1999 follow-up survey was to account for changes in status of the 239 borrowers who were surveyed in 1994. Table 1 depicts changes in borrower status over the 1994-99 period by sex, gender, type of enterprise, and rural or urban location. Surprisingly, out of the original 239 borrowers, only 58 of these remained as current borrowers in FUNDAP's credit program. Retention rates in the microcredit program were higher for urban entrepreneurs than for rural entrepreneurs $(37.3 \%$ to $20.0 \%$, $p$-value $=0.005$ ), borrowers over the age of 35 relative to those under 35 years old $(30.5 \%$ to $18.1 \%$, p-value $=0.024)$, and those involved in the service industry as opposed to those involved in manufacturing $(38.1 \%$ to $20.1 \%$, p-value $=0.005)$. The retention rate was also higher for women, though not statistically significant, $29.6 \%$, compared to $22.2 \%$ for men $(\mathrm{p}$-value $=0.235)$. Drop-out rates in the Guatemalan credit program were much higher than those reported by Khandker 1995) for the Grameen Bank, which fluctuated annually between 3 to $4 \%$ from 1986-94.

Table 1 also shows that fluidity out of entrepreneurial activity and into both domestic and international labor markets was also greatest for young, rural, males with manufacturing enterprises. Ten of the original 239 entrepreneurs participated in the credit program in 1994 abandoned entrepreneurial activity between 1994 and 1999 for wage employment in Guatemalan firms; nine of these were men. More than three times this number abandoned entrepreneurial activity for emigration to the United States. Of the 31 borrowers who emigrated to the United States during 1994-1999, nearly all were 
young men in rural areas involved in the manufacturing of corte, the traditional Guatemalan cloth. In Paxtaca, a rural village of not more than a few thousand residents, we were told by village residents that several hundred men from the village were living in Houston, working as gardeners, carpenters, and textile workers. Former borrowers in the credit program were reported by their families to earn from $\$ 7-\$ 10$ an hour for work in the United States, ten to fifteen times the net income per hour estimated for the typical entrepreneur in the sample involved in corte production. For these men, entrepreneurial activity became a stepping stone to financing the costly entry (primarily through illegal immigration by land through Mexico) into the US labor market.

The emigration to the United States of such a significant fraction of the participants in the credit program was surprising, especially since one of the stated goals of FUNDAP's credit program has been to mitigate rural-to-urban and international migration though the development of small enterprises in rural areas. Two important factors may have accounted for this phenomenon. The first was a booming US economy during the mid-to-late 1990s, which created a huge demand for unskilled and semi-skilled labor in U.S. urban areas such as Los Angeles, Phoenix, and Houston. With U.S. unemployment continuing to fall during the 1990s, large numbers of low-income workers moved into higher paying jobs, leaving a large number of vacancies in unskilled positions. The sharp increase in demand in the U.S. for unskilled and semi-skilled labor in booming industries such as construction, pushed up wages and, perhaps most importantly, reduced political pressure to crack down on illegal immigration and undocumented workers in southern urban areas.

The second factor responsible for this emigration was a decline in wholesale prices of corte. Nearly all the entrepreneurs who abandoned businesses for US emigration 
were young, male entrepreneurs involved in this industry. Due to increases in competition from South American producers of native textiles and from machine-made substitutes, wholesale prices paid by buyers of the traditional cloth fell during this period. However, the fall in corte prices was likely exacerbated by the heavy concentration of financing of the corte industry by FUNDAP and other microfinance institutions in the early and mid-1990s. During this period, microfinance institutions sought to foster a resurgence of artesian industry in the western Guatemalan highlands. This is seen clearly in the 1994 sample in which 67 out of 176 rural borrowers were involved in corte production. Moreover, the fraction of participants in the credit program involved in the industry was dramatically higher in many villages, often approaching $60-80 \%$ of borrowers in a given village. The resulting surge in corte output contributed to both lower prices of the cloth at the local wholesale level and to increases in the cost of inputs (especially wool, silk, and hired labor). US emigration of many of the operarios (hired corte laborers) also put upward pressure on labor costs for entrepreneurs in the industry, reducing profit margins, and encouraging emigration of the entrepreneurs themselves.

\section{CHANGES IN EMPLOYMENT AND INCOME 1994-1999}

By the time of the 1994 survey, the amount of full-time hired labor in enterprises in the sample had grown by $87.2 \%$ from the time entrepreneurs had received their first loan. (This time period since receiving the first loan until the 1994 survey ranged from six months to six years.) Employment within the enterprises of the 239 entrepreneurs in the survey had increased from an average of 0.93 to 1.74 employees per enterprise. This $87.1 \%$ increase in hired labor is strikingly similar to the $83.4 \%$ increase in hired labor realized by the 1999 control group within the first year of receiving their initial loan, 
where employment increased from an average of 1.09 to 2.01 employees. The increase is especially remarkable since in the five years before entry into the credit program, the rate of employment growth in the control group had been barely positive. Both of these examples illustrate the powerful initial effect of credit access on microenterprise growth.

The initial growth in hired labor, however, was not sustained after 1994, especially among enterprises who dropped out of the credit program. Hired labor tended to plateau from 1994-99 for borrowers who remained in the credit program, increasing by only $5.7 \%$. In enterprises that no longer participated in the program, hired labor actually declined by $31.7 \%$. Moreover, Table 2 shows that employment increased in all subcategories for current borrowers during the time period 1994-1999, yet for entrepreneurs who had left the credit program employment declined in each borrower category. Yet employment growth in these enterprises that remained in the program was dramatically slower than during the period previous to 1994.

While the data reveal a sharp and powerful effect of credit access on employment generation in initial the months following credit access, especially for small manufacturing enterprises, the data also reveal a pattern in which employment growth thereafter peaks quite abruptly. After employment increased $87.1 \%$ in the enterprises in the sample before 1994, the total number of full-time employees in the 239 enterprises actually declined by $19.3 \%$ from 1994 to 1999 as seen in Table 2 . It seems impossible to blame lackluster macroeconomic conditions of the period for the decline; toward the end of the same period, enterprises in the control group (who had recently received their own first credits) reported an $83.4 \%$ surge in employment.

What then explains this pattern of rapid growth in hired labor after initial credit access followed by a substantial slowdown or decline? There appear to be a number of 
factors responsible for this phenomenon. While one set of factors is more general and will be discussed later, a second set of factors is specific to the western Guatemala region and the corte industry. Much of the decline in hired labor was realized in enterprises involved in the rural manufacturing of corte. While employment in manufacturing enterprises involved in corte production fell $24.3 \%$, employment in other manufacturing enterprises declined by only $2.8 \%$. For borrowers continuing in the program, differences were even greater: a decline of $-16.0 \%$ and an increase of $55.0 \%$ respectively.

Some of this difference stemmed from the heavy impact on the corte industry by international emigration. Due to the problems discussed earlier which led to falling wholesale prices for corte, operarios employed in the production of corte displayed abnormally high rates of emigration to southern urban cities in the United States during 1994-99, contributing to a decline in employment in these enterprises.

But along with emigration, there was an additional factor responsible for employment declines in corte enterprises: a re-organization of the corte industry resulting from labor market failures in corte production. For an entrepreneur producing corte, hiring new operarios involves a costly process of training workers in the fabrication of the traditional Mayan designs and patterns in the cloth. However, entrepreneurs frequently fail to realize a sufficient return on these training costs, since after being trained, operarios may leave to establish their own corte enterprises.

The heavy microfinancing of the industry begun in the early 1990s brought about substantial increases in employment within these enterprises. The effect of the market failure for operarios was a reluctance of corte producers to hire and train new workers, and the subsequent dispersal of production over a large number of family enterprises in the village. Many of the somewhat larger producers then began act also as comerciantes, 
purchasing corte from other producers in their villages (many being former employees), bringing both their own product and that of other producers to the market. This in part explains why gross income in these enterprises remained strong while the number of employees declined during the time of the study (see Tables 2 and 3).

A second result of the market failure for operarios was the consolidation of the corte industry within the family sphere, and the substitution of family labor for hired labor. Family labor was often used in the production of corte because training costs are more easily recovered by the entrepreneur. Between the 1994 and 1999 surveys, the labor of daughters, especially, was often substituted for the labor of hired operarios. The reason the labor of daughters was preferred to that of sons was said to be related to the fact that rural Mayan women often marry in their mid-teens. In the eyes of parents, this appears to reduce the return to household investment in schooling for daughters, and thus lowering the opportunity cost to their labor in the family enterprise. In terms of the effects of credit access on schooling, the corte industry was clearly one in which the "family-enterprise-capitalization" effect outweighed the "family-labor-substitution" effect (Wydick 1999a). In some areas, such as the rural areas around Totonicapan, the ratio of daughters to sons laboring in family manufacturing enterprises was as high as two-to one.

While factors specific to the Guatemalan case undoubtedly hindered the growth of a number of enterprises in the sample, factors not specific to the Guatemalan context were perhaps the most powerful constraints to their growth. It was these more powerful forces that appeared to place a virtual ceiling on enterprise growth past a certain size. Only one of the 239 enterprises in the sample had grown to as large as 12 hired employees; the second largest enterprise had grown to only 8 employees. The vast 
majority of the enterprises in the sample appeared to plateau at not more than two or three employees. The average number of hired employees by 1999 was equal to 1.33 , while the average number of family laborers working in enterprises (other than the entrepreneur) was nearly equivalent at 1.30 .

The first factor responsible for such sharply diminishing returns to capital and labor in these enterprises was the level of formal education among the entrepreneurs. The mean time spent in formal education was only 2.9 years among entrepreneurs in the sample. Moreover, this statistic may in fact overestimate the level of formal education of entrepreneurs within the sample; the quality of rural public education in Guatemala is notoriously poor.

Nevertheless, microenterprises entrepreneurs with only a few years of basic primary education appear to be quite capable of training and supervising up to two or three employees, especially with the help of another family member. Up to this point, employment growth in these enterprises was quite rapid (Wydick, 1999b). At this scale of enterprise, entrepreneurial activity involves primarily skill transfer to workers and direct supervision of labor. However, growing a business past a handful of hired laborers requires a more complex set of managerial skills that exceed those of most entrepreneurs in the sample. Sheer confidence and entrepreneurial drive appeared to be able to substitute to some extent for formal education and management training among some of the individuals in the sample, especially at low levels of hired labor. But in general, when one of these qualities was lacking, businesses routinely stagnated, and when both of these qualities were lacking, businesses declined.

An additional factor that appeared to strongly constrain employment growth in enterprises was the threat of government regulation and taxation of larger businesses. At 
least until very recently, the informal sector has been widely ignored by Guatemalan authorities. ${ }^{3}$ This has presented both obstacles and benefits to microenterprise entrepreneurs. While there has been no cohesive plan on the part of the government to aid the informal sector, microenterprises have also been left almost completely unharassed by federal labor and safety laws, and have been able to escape taxation. As a result, operating a microenterprise with only a few hired employees allows an entrepreneur to stay inconspicuously "under the radar" of a watchful government eye. Adding a larger number of hired workers is risky for entrepreneurs because it puts them in jeopardy of being hit with regulations and taxes. The marginal profit of the hired laborer who attracts government attention to the enterprise is almost certainly negative. Aside from direct costs of government permitting, regulation, and taxation, the pressure of compliance to these requirements is particularly intimidating for entrepreneurs without many years of formal education.

Interestingly, although employment declined over the study period, sales revenue continued to increase at an annual rate of several points greater than the rate of inflation. Sales revenue for borrowers who remained with the credit program increased $97.1 \%$ over the five-year period (in current levels of currency), while revenue of borrowers who left the program increased $76.1 \%$. Both of these figures exceeded the increase in the Guatemalan inflation, which according to the Bank of Guatemala increased $45.5 \%$ during 1994-99. Revenue for the control group during this period increased only $49.2 \%$, or virtually the same as inflation. The primary difference between the control group and those borrowing from the credit program since 1994 is among service/retail enterprises, who through large increases in borrowing over time were able to expand inventories greatly such that large increases in sales revenue were possible with little or no increase 
in employment. Overall changes in sales by manufacturers were similar between those in the credit program and those in the control group.

\section{GENDER DIFFERENCES IN RESPONSE TO CREDIT ACCESS}

There is much in the existing literature that emphasizes gender differences in response to credit access. The working hypothesis of the literature is that male entrepreneurs tend to divert a greater percentage of profits to reinvestment in an enterprise, while female entrepreneurs in developing countries tend to allocate a greater share of profits toward food, clothing, and other expenditures affecting child welfare and health. Jiggins (1989), for example, argues that a primary goal of female entrepreneurs is to ensure subsistence consumption for members of the household. Male entrepreneurs, in contrast, are characterized as somewhat greater risk-takers, engaged in higher-yielding, but potentially riskier, projects. Downing (1990) also highlights the strong relationship between female entrepreneurial activity and children's welfare, arguing that women have a predisposition to use profits to meet family needs rather than to reinvest in and grow small businesses. Pitt and Khandker (1998) reveal stronger increases in household consumption for female entrepreneurs in Bangladesh, showing that household consumption expenditure increased 18 taka for every 100 additional taka borrowed by women while the increase was only 11 taka for every 100 taka borrowed by men. The logical policy conclusion from this research is that if the development objective is to foster employment generation, it may be better to lend to male entrepreneurs. If it is to reduce child poverty, it may be better to target loans at female entrepreneurs.

The Guatemalan data offer qualified support for the idea that microcredit programs tend to spur relatively greater increases in household consumption for female 
borrowers, but relatively larger levels of business investment for male borrowers. While Table 4 indicates that $64.3 \%$ of entrepreneurs maintain that they were able to expand their businesses (in terms of output for manufacturers or holding a greater array of inventory, for example, for retailers), the figure was five percentage points higher for men than for women, though this difference is not statistically significant $(\mathrm{p}$-value $=$ 0.480 ). While $56.5 \%$ of the 239 entrepreneurs in the survey responded that they had used loans to purchase new equipment, the figure was dramatically higher for men, $64.1 \%$ to $39.2 \%(p-v a l u e=0.000)$. Part of the reason for this difference, however, is the greater presence of female entrepreneurs in retail rather than manufacturing enterprises.

A greater proportion of men than women indicated that access to credit had allowed them to add hired labor to their enterprises, 35.5 to $29.4 \%$ ( $\mathrm{p}$-value $=0.336$ ). Yet as Table 2 indicates, male entrepreneurs also shed labor at a greater rate than female entrepreneurs during the five years of the study; declines in employment tended to be greatest during 1994-99 in categories where employment growth had been strongest up to 1994. Thus employment gains were greater for male entrepreneurs, but so also was volatility of employment within these enterprises.

It is worth noting that the alleged advantage in employment generation of male over female entrepreneurs is subject to some interesting qualifications. Wydick and Kevane (2001) find using the 1994 Guatemalan data that the advantage of male over female entrepreneurs in employment generation holds only with women who are in childbearing and early childraising years. Econometric simulations show that as entrepreneurs approach middle age, the difference in employment generation appears to actually reverse itself (controlling for other factors), with older women actually adding more hired labor to their enterprises than older men. 
There were clear gender differences in the sample for labor preferences within the enterprise. In the sample, $66.7 \%$ of women preferred supervising family labor in their enterprises, $8.3 \%$ preferred hired labor, and $25.0 \%$ were indifferent. Male entrepreneurs also preferred family labor, but at a lower rate, $56.1 \%$, while $25.8 \%$ preferred higher labor, and $19.7 \%$ were indifferent. Women typically responded during the survey that they preferred family labor because family members were more reliable, honest, and required less supervision. In contrast, several male entrepreneurs indicated that they preferred hired laborers because "if they don't work hard, they can be fired."

However, male entrepreneurs actually employed more family labor than female entrepreneurs, 1.48 per enterprise to 0.86 for females. (Though this number is exaggerated by the fact that wives work in husbands' enterprises much more commonly than vice versa.) Furthermore, male entrepreneurs had both higher percentages of both child and family labor working in their enterprises. This is likely due to the advantageous bargaining position of male to female entrepreneurs over household resources.

Other business variables showed similar responses between male and female entrepreneurs to credit access. As Table 4 shows, a similar percentage of women and men in the sample (58.8\% and 56.4\%, respectively) indicated that one effect of access to credit had been to make their enterprises more stable, and profits less volatile, over the course of the high and low seasons of a year. About $72 \%$ of both men and women also indicated that access to the credit program had allowed them to increase business sales. Note that the difference between this figure and that in Table 2 is that the figure in Table 4 captures the percentage of respondents who attribute an increase in enterprise sales to access to the credit program. 
The 1999 survey asked those that had participated in the credit program to rank their uses of profits from their business from most important use (1) to least important use (3), as seen in Table 5. It was found by pilot surveys that by far the most common ways that people in western Guatemala saved and accumulated assets was to purchase agricultural land. (Fairly well-functioning land markets in the area offer rural households access to a stable and appreciating asset in western Guatemala, where population densities are high and growing.) Thus the three choices to be ranked in order of importance were using business profits to (a) re-invest in the business enterprise, (b) purchase food and clothing for family members, (c) save to purchase land.

Gender differences were clear in the response to the question. The first priority on average for male entrepreneurs was business re-investment, with food and clothing purchases second, ranked close to saving to purchase land. As Table 5 shows, the first priority for use of profits by female entrepreneurs was purchase of food and clothing, while business investment was second, and saving for land third.

Borrowers in the Totonicapan region were administered additional questions in the 1999 survey regarding changes in land ownership over the 1994-99 period. Among 49 male borrowers in this area land holdings increased from 6.86 to 8.22 cuerdas (one cuerda is equal to about 500 square meters), or an increase of $19.9 \%$. The households of the 11 female entrepreneurs surveyed in the Totonicapan region increased their land holdings from 3.5 to 4.5 cuerdas, a smaller absolute increase, but a greater percentage increase $(28.6 \%)$. Thus at least in this region, while savings and asset accumulation may rank as a lower priority for women, it remains an important outcome of credit access for female as well as male entrepreneurs. 
Male entrepreneurs maintained at a greater rate than female entrepreneurs $(77.8 \%$ to $68.6 \%$, $p$-value $=0.163)$ that access to credit had allowed them to make structural improvements to the family home. The most substantial improvements seen in some entrepreneurs homes during the course of the survey were replacing adobe walls with stronger cinder-block walls, which are more resistant to earthquakes and allow second stories to be added to homes. Approximately equal percentages of men and women, about $46 \%$, said that access to credit had allowed them to generate sufficient profits that they could buy new household appliances such as a refrigerator, mixer, or oven. Male and female entrepreneurs were also roughly equal in the proportion maintaining that access to credit had sufficiently impacted their enterprises such that it allowed their children to progress farther in school, about $65 \%$ for both groups. An only slightly higher proportion of women maintained that the growth in their businesses stemming from credit access had allowed them to purchase a greater amount of food and clothing for children, $78.4 \%$ to $75.9 \%$, p-value $=0.681)$. Gender differences in the impact of access to credit on savings are statistically insignificant, but perhaps slightly larger for females, with $54.9 \%$ of women and $47.9 \%$ of men indicating that access to credit had fostered in increase in their savings ( $\mathrm{p}$-value $=0.336$ ).

Taken together, these self-reported impacts of the credit program indicate that positive impacts from the microcredit program were widespread, but not universal. While the great majority of those who were borrowers in the program in 1994 indicated qualitatively positive impacts from the program, a significant minority indicated little or no improvement in simple self-reported indicators of household welfare. The results from the study also indicate that for some variables there do exist significant gender differences in response to access to credit, though in many cases they are statistically 
insignificant. Nevertheless discernable patterns are evident in the data in differential credit impacts between male and female entrepreneurs with respect to employment generation, increases in enterprise capitalization, and use of profits. In most cases gender differences are not large, and may frequently be attributed to patterns in the female lifecycle (Wydick and Kevane, 2001).

\section{SUMMARY AND CONCLUSIONS}

The survey of 239 participants in a microcredit program in 1994 and the subsequent follow-up survey of these borrowers in 1999 reveal both the benefits and limitations of microcredit programs. Substantial increases in enterprise employment and sales revenue were found in the 1994 survey since the time these entrepreneurs had gained initial credit access. The 1999 survey found that a majority of these enterprises had peaked in employment creation, and many had actually experienced declines in enterprise employment. Factors such as foreign emigration and shrinking profit margins for certain types of manufactured goods during the period of study certainly played important roles in limiting enterprise. Nevertheless, there also appear to the other more important and deeply rooted factors that work against the long-term growth of microenterprises in developing countries, even as they continue to receive access to substantial amounts of credit from a microfinance institution.

It is significant that not one of the enterprises surveyed in 1999 reached the size of what one might reasonably call a medium-sized business. As an enterprise grows to perhaps 10 to 15 employees, the role of the entrepreneur must change from that of a supervising co-worker to that of a manager. None of the entrepreneurs in the sample clearly made that transition. Thus an important policy implication from this research is 
that access to credit may be a binding constraint to growing an enterprise from, for example, self-employment to an enterprise with five hired workers. But that there are other constraints, such as human capital and formal management skills, which inhibit growth past this point (see also Haynes, Seawright, and Giauque, 2000). The development of somewhat more advanced management programs for credit program participants, necessary to move entrepreneurs to this next level, is one evident policy implication of this research.

A second conclusion from this research is that there do indeed exist gender differences in response to credit access. While many of these differences may be attributable to traditional duties of women during childbearing and childraising years, and not to innate differences in entrepreneurial ability, women in this study clearly expressed a greater desire to use enterprise profits for household consumption rather than business re-investment than their male counterparts. Female enterprises were also more stable, showing somewhat lower rates of employment growth previous to the 1994 survey, but also showing a smaller decline in hired labor than male enterprises during the 1994-1999 period. Female entrepreneurs also exhibited to higher retention rates in the program. Future research should seek to ascertain the consistency of these findings in other areas, where there exists a different mix in types of enterprises and other exogenous factors. Future research should also seek to examine long-term effects of credit access vis-a-vis other types of microfinance institutions such as village banks or credit cooperatives. It is only then that one would be able to ascertain whether these findings are indeed generalizable across developing country contexts. As greater resources are channeled into microcredit programs as tools for alleviating poverty, it is critical to understand both the benefits and the limitations of credit market interventions. 


\section{Footnotes}

${ }^{1}$ Fundation para el Desarrollo Integral de Programas Socioeconomicos (FUNDAP) or Foundation for the Integrated Development of Socioeconomic Programs based in Quetzaltenango, Guatemala.

${ }^{2}$ Major entrants into the market for microcredit now include BanRural, a large Guatemalan bank that has effectively used new credit delivery technology to reach small enterprises, FUNDESPE, or Foundation for the Development of the Small Entrepreneur, an NGO that has operated in the area since the early 1990's, and $\mathrm{Fe}$ y Alegria, a smaller faith-based microfinance institution.

${ }^{3}$ In 2000 the Lopez-Portillo government introduced a new tax on small enterprises, which has affected many of those in the informal sector who had been previously exempt from such taxes. 
$\underline{\text { Tables }}$

Table 1: Borrower Movement 1994-1999

\begin{tabular}{|l|r|r|r|r|r|r|r|r|r|}
\hline & male & female & $>35$ & $\leq 35$ & manuf & service & urban & rural & total \\
\hline Current Borrower & 39 & 19 & 36 & 22 & 37 & 21 & 22 & 36 & $\mathbf{5 8}$ \\
\hline Not Current Borrower & 81 & 32 & 53 & 60 & 87 & 26 & 33 & 80 & $\mathbf{1 1 3}$ \\
\hline Emigrated to US & 28 & 3 & 8 & 23 & 30 & 1 & 0 & 31 & $\mathbf{3 1}$ \\
\hline Employed-Other Firm & 9 & 1 & 5 & 5 & 7 & 3 & 2 & 8 & $\mathbf{1 0}$ \\
\hline Ref. to Particip. 1999 & 3 & 2 & 4 & 1 & 4 & 1 & 2 & 3 & $\mathbf{5}$ \\
\hline Passed Away 94-99 & 2 & 2 & 4 & 0 & 4 & 0 & 0 & 4 & $\mathbf{4}$ \\
\hline Unable to Locate & 13 & 5 & 8 & 10 & 15 & 3 & 4 & 14 & $\mathbf{1 8}$ \\
\hline total & $\mathbf{1 7 5}$ & $\mathbf{6 4}$ & $\mathbf{1 1 8}$ & $\mathbf{1 2 1}$ & $\mathbf{1 8 4}$ & $\mathbf{5 5}$ & $\mathbf{6 3}$ & $\mathbf{1 7 6}$ & $\mathbf{2 3 9}$ \\
\hline
\end{tabular}

Source: 1994 and 1999 Guatemala Field Surveys

Table 2: Changes in Hired Labor 1994-1999

\begin{tabular}{|r|r|r|r|r|r|r|}
\hline & male & female & $\begin{array}{l}\text { Current } \\
\text { Borrowers }\end{array}$ & $\begin{array}{r}\text { No Longer } \\
\text { in Program }\end{array}$ & $\begin{array}{r}\text { Control } \\
\text { Total } \\
\text { Group }\end{array}$ \\
\hline $\mathbf{3 5}$ & $-33.7 \%$ & $-15.6 \%$ & $9.4 \%$ & $-51.9 \%$ & $\mathbf{- 2 7 . 6 \%}$ & $\mathbf{2 . 5 \%}$ \\
\hline $\mathbf{3 5}$ & $-15.4 \%$ & $30.8 \%$ & $0.0 \%$ & $-14.7 \%$ & $\mathbf{- 1 1 . 0 \%}$ & $\mathbf{5 . 3 \%}$ \\
\hline Urban & $0.0 \%$ & $-25.0 \%$ & $55.6 \%$ & $-27.6 \%$ & $-\mathbf{7 . 9 \%}$ & $\mathbf{9 . 2 \%}$ \\
\hline Rural & $-26.3 \%$ & $0.0 \%$ & $0.0 \%$ & $-31.8 \%$ & $\mathbf{- 2 1 . 1 \%}$ & $\mathbf{4 . 3 \%}$ \\
\hline Corte & $-28.2 \%$ & $-9.7 \%$ & $-16.0 \%$ & $-28.6 \%$ & $\mathbf{- 2 4 . 3 \%}$ & $\mathbf{7 . 1 \%}$ \\
\hline Manuf (not corte) & $-17.5 \%$ & $57.1 \%$ & $55.0 \%$ & $-25.5 \%$ & $\mathbf{- 2 . 8 \%}$ & $\mathbf{4 . 8 \%}$ \\
\hline Service & $-18.2 \%$ & $-61.5 \%$ & $16.7 \%$ & $-47.1 \%$ & $\mathbf{- 6 . 3 \%}$ & $\mathbf{2 . 6 \%}$ \\
\hline Total & $\mathbf{- 2 3 . 1 \%}$ & $\mathbf{- 5 . 2 \%}$ & $\mathbf{5 . 7 \%}$ & $\mathbf{- 3 1 . 7 \%}$ & $\mathbf{- 1 9 . 3 \%}$ & $\mathbf{3 . 9 \%}$ \\
\hline Control Group & $\mathbf{4 . 9 \%}$ & $\mathbf{0 . 0 \%}$ & -- & -- & $\mathbf{3 . 9 \%}$ & $\mathbf{3 . 9 \%}$ \\
\hline
\end{tabular}

Source: 1994 and 1999 Guatemala Field Surveys

Table 3: Changes in Gross Income 1994-1999

\begin{tabular}{|r|r|r|r|r|r|r|}
\hline & male & female & CB & NC & Total & $\begin{array}{c}\text { Control } \\
\text { Group }\end{array}$ \\
\hline $\mathbf{3 5}$ & $92.4 \%$ & $73.9 \%$ & $97.3 \%$ & $78.7 \%$ & $\mathbf{8 6 . 3 \%}$ & $\mathbf{2 0 . 7 \%}$ \\
\hline $\mathbf{3 5}$ & $84.8 \%$ & $65.4 \%$ & $96.9 \%$ & $73.7 \%$ & $\mathbf{8 0 . 0} \%$ & $\mathbf{7 9 . 0 \%}$ \\
\hline Urban & $117.1 \%$ & $70.8 \%$ & $96.0 \%$ & $91.1 \%$ & $\mathbf{9 3 . 1 \%}$ & $\mathbf{3 2 . 1 \%}$ \\
\hline Rural & $80.7 \%$ & $70.0 \%$ & $97.9 \%$ & $70.0 \%$ & $\mathbf{7 8 . 7 \%}$ & $\mathbf{6 6 . 9 \%}$ \\
\hline Corte & $72.3 \%$ & $102.9 \%$ & $75.2 \%$ & $78.1 \%$ & $\mathbf{7 7 . 4 \%}$ & $\mathbf{3 3 . 6 \%}$ \\
\hline Non-Corte Manuf & $106.0 \%$ & $26.6 \%$ & $51.5 \%$ & $92.4 \%$ & $\mathbf{8 0 . 2} \%$ & $\mathbf{9 5 . 6 \%}$ \\
\hline Service & $103.8 \%$ & $76.9 \%$ & $133.3 \%$ & $61.5 \%$ & $\mathbf{9 8 . 3 \%}$ & $\mathbf{2 8 . 4 \%}$ \\
\hline Total & $\mathbf{8 8 . 6 \%}$ & $\mathbf{7 0 . 4 \%}$ & $\mathbf{9 7 . 1 \%}$ & $\mathbf{7 6 . 1 \%}$ & $\mathbf{8 3 . 3 \%}$ & $\mathbf{4 9 . 2 \%}$ \\
\hline Control Group & $\mathbf{4 1 . 3 \%}$ & $\mathbf{5 7 . 3 \%}$ & -- & -- & $\mathbf{4 9 . 2 \%}$ & \\
\hline
\end{tabular}

Source: 1994 and 1999 Guatemala Field Surveys 
Table 4: Impacts of Credit: Enterprise

\begin{tabular}{|l|r|r|r|}
\hline & Total & Men & Women \\
\hline $\begin{array}{l}\text { *Business Benefit: } \\
\text { (\% responding yes) }\end{array}$ & & & \\
\hline Business extended & $64.3 \%$ & $65.8 \%$ & $60.8 \%$ \\
\hline Bought new equipment & $56.5 \%$ & $64.1 \%$ & $39.2 \%$ \\
\hline More stable & $57.1 \%$ & $56.4 \%$ & $58.8 \%$ \\
\hline Sales growth & $71.4 \%$ & $70.9 \%$ & $72.5 \%$ \\
\hline New employees & $33.9 \%$ & $35.9 \%$ & $29.4 \%$ \\
\hline Employee Preference: & & & \\
\hline Family & $59.8 \%$ & $56.1 \%$ & $66.7 \%$ \\
\hline Hired labor & $19.6 \%$ & $25.8 \%$ & $8.3 \%$ \\
\hline Indifferent & $21.6 \%$ & $19.7 \%$ & $25.0 \%$ \\
\hline Source: 1999 Guatemala Field Survey & & & \\
\end{tabular}

Table 5: Impacts of Credit: Household

\begin{tabular}{|l|r|r|r|}
\hline & Total & Men & Women \\
\hline $\begin{array}{l}\text { Use of Profits: mean ranking } \\
\text { (1=most imp, 3=least imp.) }\end{array}$ & & & \\
\hline Reinvest in business & 1.756 & 1.730 & 1.820 \\
\hline Buy food & 1.900 & 2.027 & 1.569 \\
\hline Purchase land & 2.311 & 2.186 & 2.588 \\
\hline $\begin{array}{l}\text { *Household Benefit: } \\
\text { (\% responding yes) }\end{array}$ & & & \\
\hline Home improvements & $75.0 \%$ & $77.8 \%$ & $68.6 \%$ \\
\hline New appliances & $46.4 \%$ & $47.0 \%$ & $45.1 \%$ \\
\hline More savings & $50.0 \%$ & $47.9 \%$ & $54.9 \%$ \\
\hline New clothes for children & $76.6 \%$ & $75.9 \%$ & $78.4 \%$ \\
\hline More education for children & $64.9 \%$ & $65.0 \%$ & $64.7 \%$ \\
\hline
\end{tabular}

Source: 1999 Guatemala Field Survey 


\section{$\underline{\text { References }}$}

Clark, Mari H., (1991) "Gender Issues in Microenterprise Assistance," Studies in Third World Societies Vol. 44, pp.109-133.

Coleman, Brett E. (1999) “The Impact of Group Lending in Northeast Thailand," Journal of Development Economics, Vol 60, October, pp. 105-141.

Downing, J. (1990) "Gender and the Growth and Dynamics of Microenterprises," Washington D. C.: U.S. Agency for International Development, Private Enterprise Bureau.

Haynes, C. Beth, Seawright, Kristie, and William Giauque (2000) "Moving Microenterprises beyond a Subsistence Plateau" Journal of Microfinance, Vol. 2, No. 2, pp.131-52.

Khandker, Shahidur R. (1998) Fighting Poverty with Microcredit, New York: The World Bank/Oxford University Press.

Mosley, Paul, and David Hulme. (1996) Finance Against Poverty. London: Routeledge.

Morduch, Jonathan. (1998) "Does Microfinance Really Help the Poor? Evidence from Flagship Programs in Bangladesh," Hoover Institution, Stanford U. mimeo.

Jiggins, Janice. (1989) "How Poor Women Earn Income in Sub-Saharan Africa and What Works Against Them," World Development, Vol. 17, No.7, pp.953-963.

Khandker, Shahidur R. (1995) The Grameen Bank : Performance and Sustainability Washington, D.C. : World Bank.

Khandker, Shahidur R. (1998) Fighting Poverty with Microcredit : Experience in Bangladesh. New York : Oxford University Press.

Kevane, Michael, and Bruce Wydick. (2001) "Social Norms and the Time Allocation of Women's Labor in Burkina Faso," Review of Development Economics, Vol. 5, No. 1, pp.119-129.

Pitt, Mark and Khandker, Shahidur. (1998) "The impact of group-based credit programs on poor households in Bangladesh: does the gender of participant matter," Journal of Political Economy, Vol. 106(5):958-95.

Wydick, Bruce. (1999) "The Effect of Microenterprise Lending on Child Schooling in Guatemala," Economic Development and Cultural Change, Vol. 47, No. 4, pp. 853-869.

Wydick, Bruce. (1999) "Credit Access, Human Capital, and Class Structure Mobility," Journal of Development Studies, Vol. 35, No.6, pp.131-52. 